\title{
Analysis of cardiac and pulmonary injuries resulting from an experimental penetrating thoracic injury
}

\author{
Mahmut Tokur, M.D., ${ }^{1}$ Mehmet Ergin, M.D., ${ }^{2}$ Mehmet Okumuş, M.D. ${ }^{3}$ \\ ${ }^{1}$ Department of Thoracic Surgery, Sutcu Imam University Faculty of Medicine, Kahramanmaras; \\ ${ }^{2}$ Department of Emergency Medicine, Konya Necmettin Erbakan University Faculty of Medicine, Konya; \\ ${ }^{3}$ Department of Emergency Medicine, Sutcu Imam University Faculty of Medicine, Kahramanmaras
}

\begin{abstract}
BACKGROUND: This study was planned to analyze the internal and external anatomical findings of cardiac injuries and the presence of accompanying pulmonary injuries in intentionally inflicted thoracic injuries to swine models.

METHODS: We inflicted a penetrating heart injury in six suis domesticus female swine models. Two cardiac injuries, one on the left paratracheal of fourth intercostal space (ICS) and the other on the right side were inflicted on each model by the same researcher using a $20-\mathrm{cm}$ long scalpel. All animals were then sacrificed for morphological evaluation.

RESULTS: After strikes to the left fourth ICS, external evaluation showed that $50 \%$ of the subjects suffered a single laceration and that $33 \%$ suffered multiple lacerations. Internal evaluation showed additional intracardiac injuries in all five subjects. However, the subject that suffered a single laceration on the outer surface of the heart had multiple internal injuries while another subject that had multiple outer lacerations had only one intracardiac injury. Only three subjects suffered cardiac injuries and only two out of those three with pulmonary injuries after right fourth intercostal intrusions.
\end{abstract}

CONCLUSION: This experiment has shown that external evaluation of the heart tissue may not alone be sufficient to determine the extent of cardiac injuries and accompanying pulmonary injuries caused by penetrating thoracic injuries.

Key words: Myocardial injury; penetrating; trauma.

\section{INTRODUCTION}

Although rarely seen, penetrating heart injuries are important thoracic pathologies because they carry a high-risk for mortality and require rapid diagnosis and treatment. ${ }^{[1]}$ We conducted this study to analyze the internal and external anatomical findings of cardiac injuries and the presence of accompanying pulmonary injuries in intentionally inflicted thoracic injuries to swine models and explained the mechanisms that contribute to high mortality rates in related injuries.

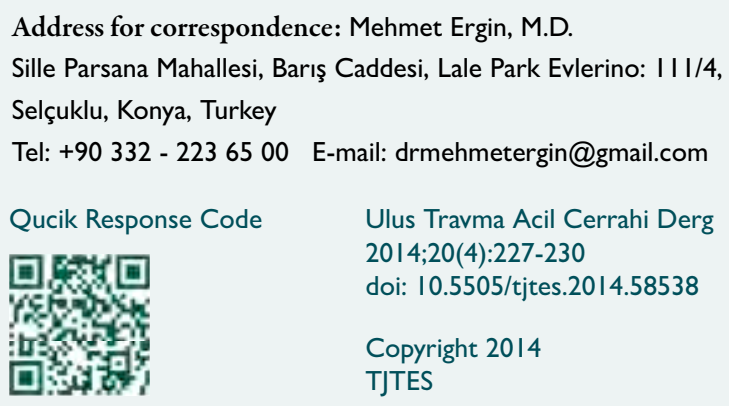

\section{MATERIALS AND METHODS}

\section{Overview of the Experimental Animal Groups}

Six suis domesticus type female swine models, all of which were I-year-old and weighed between $50 \mathrm{~kg}$ and $55 \mathrm{~kg}$, were used in this experiment. All animals were kept under 12 hour/ 12 hour light/dark cycle at a constant temperature $\left(22^{\circ} \mathrm{C}\right)$ and allowed free access to food and tap water. All experimental procedures were approved by the Cukurova University School of Medicine Ethical and Experimental Committee. All investigators complied with the 1996 "Guide for the Care and Use of Laboratory Animals." All efforts were undertaken to reduce the total number of animals required for the experiment and to minimize their discomfort. Feeding of the animals was stopped 24 hours prior to experiment, with water being available until 2 hours prior. Intravenous cannulations were performed in animals through $\mathrm{V}$. Auricularis lateralis and infusion of $0.9 \%$ isotonic saline was started at the beginning of the experiment. Atropine sulfate at $0.2 \mathrm{mg} / \mathrm{kg}$ was given to reduce secretions prior to anesthesia. Xylazine (Rompun), at a dose of $2 \mathrm{mg} / \mathrm{kg}$, and ketamine, at a dose of $13 \mathrm{mg} / \mathrm{kg}$, were started to induce anesthesia, and this combination continued 
to be infused throughout the experiment. Supplemental oxygen was provided to the subjects during the experiment.

\section{Induction of Penetrating Thorax Injury and Insertion of Catheters and Thoracotomy Operation}

Thoraces of the animals covering the sternum and ribs were shaved and then properly disinfected using povidone iodine $\left(\right.$ Batikon $^{\circledR}$ ) solution. Two cardiac injuries, one on the left paratracheal of fourth intercostal space (ICS) and the other on the right paratracheal of fourth ICS were inflicted on each model by the same researcher using a $20-\mathrm{cm}$ long scalpel (Fig. Ia). All animals were then sacrificed with high dose ketamine hydrochloride. The hearts of the animals were removed for morphological evaluation. The outer surfaces of the hearts were opened first, followed by the left ventricles and then the right ventricles and injury tracings were evaluated and classified (Fig. Ib-d). Accompanying pulmonary injuries were also detected and recorded. The data is given as a number or percentages in the text.

\section{RESULTS}

Strikes to the left fourth ICS caused cardiac injuries in all, but the third subject (Table I). All injured subjects had lacerations on the frontal surface of the left ventricle, with additional damage to coronary arteries in two of these subjects. External evaluation showed that $50 \%$ of the subjects suffered a single laceration and that $33 \%$ suffered multiple lacerations. Intracardiac evaluation showed additional injuries in all five subjects. We found a partial interventricular septum injury and a full-layer mitral valve papillary muscle injury in one subject; partial interventricular septum injury in one subject; partial mitral valve papillary muscle injury in one subject; and partial left ventricle posterior wall injuries in two subjects. Based on these observations, the subject that suffered a single laceration on the outer surface of the heart had multiple internal injuries, while subjects that had multiple external lacerations had only one intracardiac injury. All five subjects who had cardiac injuries also had pulmonary injuries.

Only three subjects suffered cardiac injuries resulting from right 4th intercostal incursion, while the other three had no injuries (Table 2). External morphological evaluation showed that all of these injuries were to the right ventricles. One subject had further damage to the apex cordis. On internal evaluation, two subjects had partial interventricular septum injuries whereas one subject had a full-layer interventricular
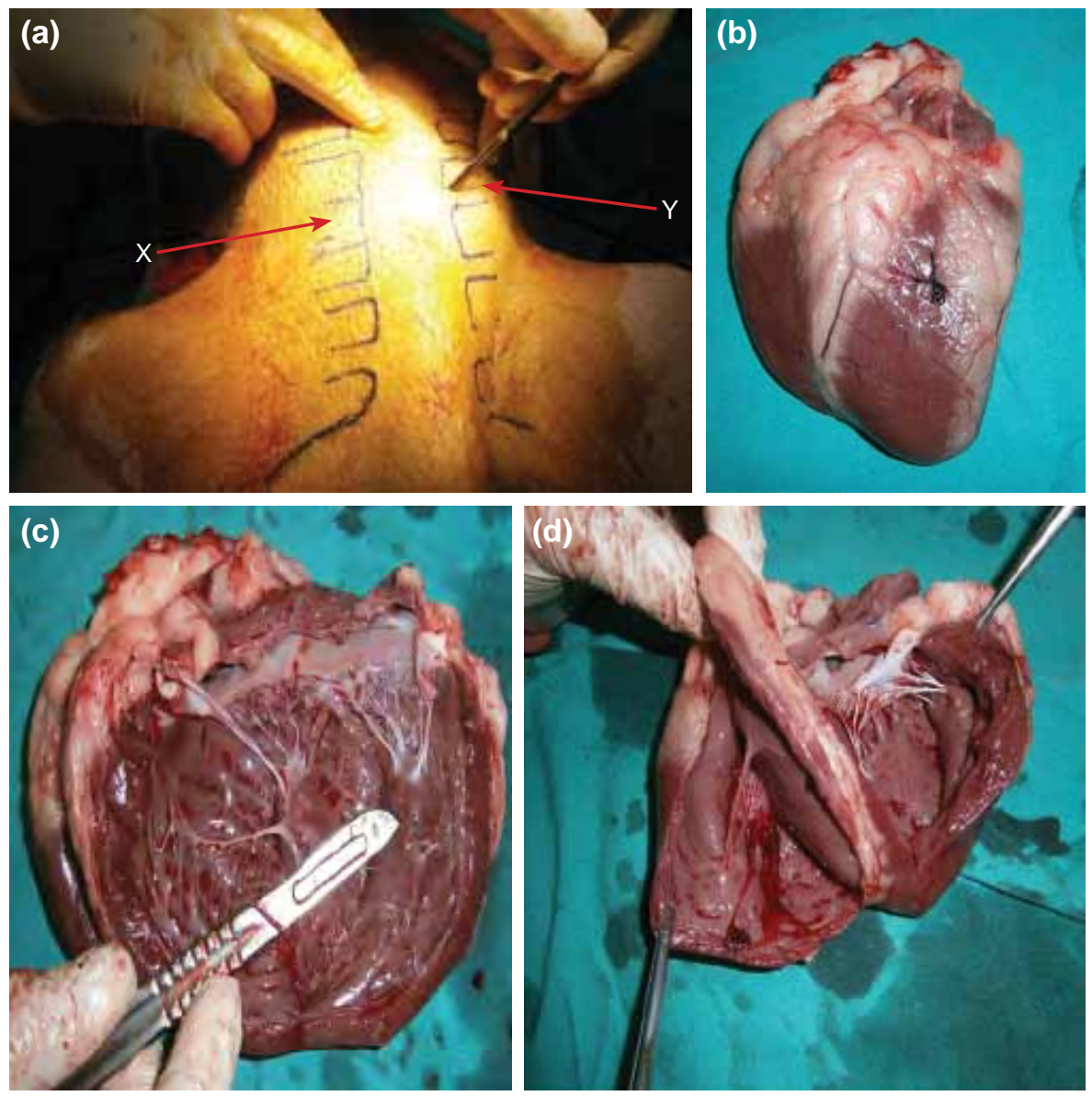

Figure 1. (a) Localization of entrance point for scalpel on both hemithorax. (b-d) The process for morphological evaluation of cardiac findings after penetrating thorax injury. 
Table I. Morphological signs explored following the injuries inflicted through the left 4th intercostal space paratracheal region

\begin{tabular}{|c|c|c|c|c|c|c|}
\hline Test subject & $\mathbf{I}$ & 2 & 3 & 4 & 5 & 6 \\
\hline \multicolumn{7}{|l|}{ External cardiac injuries } \\
\hline Left ventricle & + & + & - & + & + & + \\
\hline Coronary artery & - & + & - & + & - & - \\
\hline \multicolumn{7}{|l|}{ Internal cardiac injuries } \\
\hline Interventricular septum & + (partial) & - & - & - & - & $+($ partial $)$ \\
\hline Papillary muscle of mitral valve & + (full layer) & - & - & - & + (partial) & - \\
\hline Posterior wall of left ventricle & - & $+($ partial $)$ & - & $+($ partial $)$ & - & - \\
\hline \multicolumn{7}{|l|}{ Lung injuries } \\
\hline Left middle lobe & + & - & - & - & - & - \\
\hline Left lower lobe & - & + & + & - & + & + \\
\hline
\end{tabular}

+: Injury was present; -: Injury wasn't present.

Table 2. Morphological signs explored following the injuries inflicted through the right 4th intercostal space paratracheal region

\begin{tabular}{|c|c|c|c|c|c|c|}
\hline Test subject & $\mathbf{I}$ & 2 & 3 & 4 & 5 & 6 \\
\hline \multicolumn{7}{|l|}{ External cardiac injuries } \\
\hline Right ventricle & - & + & + & - & - & + \\
\hline Apex cordis & - & + & - & - & - & - \\
\hline \multicolumn{7}{|l|}{ Internal cardiac injuries } \\
\hline Interventricular septum & - & + (full layer) & + (partial) & - & - & + (partial) \\
\hline \multicolumn{7}{|l|}{ Lung injuries } \\
\hline Right middle lobe & - & + & - & - & - & \\
\hline Right lower lobe & - & - & - & - & - & + \\
\hline
\end{tabular}

+: Injury was present; -: Injury wasn't present.

septum injury. Only two out of those three models had accompanying pulmonary injuries.

Injury tracing in the second subject was further investigated, and it was found that the scalpel penetrated the right fourth ICS and went through the right ventricle and interventricular septum, passed the left ventricle and exited on the other side of the heart after penetrating the apex cordis. Injuries to the left ventricle and coronary artery were concluded to result from left fourth ICS penetration while the injury to the apex cordis was a result of right fourth ICS penetration.

\section{DISCUSSION}

Cardiac damage should be considered whenever injuries to the anterior thoracic region, medial to both nipples, and between the sternal jugulum and the upper abdomen are present, unless proven otherwise. ${ }^{[2]}$ In our experimental model, we were able to observe eight cardiac injuries in 12 inflicted penetrating injuries to the thorax.

There are intracardiac injuries reported in the literature fol- lowing penetrating and even blunt thoracic trauma. Tokur et al. presented a case series of II penetrating cardiac injuries that were surgically intervened. ${ }^{[3]}$ In their series, they detected a valve laceration in one patient in post-surgery echocardiography, a lacerated coronary artery in another patient during the surgery, and a left ventricle posterior wall injury in another patient. Cha et al. reported that among 7l penetrating cardiac injury patients observed over a period of 10 years, 48 survived their injuries and II had post-surgery sequales. Among their sequales were ventricular septal defects, aortic valvular damage, atrial septal defects, conduction defects, and tricuspid valvular lesions. ${ }^{[4]}$ Jenson et al..$^{[5]}$ reported a case with atrial septal defects and mitral valve anterior leaflet perforation, which were detected and surgically repaired 7 years after sustaining a penetrating cardiac injury. In another study, Stahl et al. reported a case with tricuspid and mitral valve papillary muscle rupture and intraventricular septal rupture following a blunt trauma, and concluded that indirect forces that increase intraventricular hydrostatic pressures could cause ruptures in the atria or valves. ${ }^{[6]}$ In our experiment, in which we evaluated the tracings of the injuries, we observed intracardiac injuries accompanying injuries to the external surface of the heart, with the possibility of multiple intracar- 
diac injuries even when only one injury was present on the external surface.

Tokur et al. ${ }^{[3]}$ reported accompanying pulmonary injuries in six patients out of II who suffered penetrating cardiac injuries. Similarly, Kaplan et al. ${ }^{[7]}$ reported that in a series of 63 penetrating cardiac injury cases, $34 \%$ had accompanying pulmonary injuries. In another study, Yavuz et al. ${ }^{[8]}$ reported that 54 (57.5\%) out of 94 patients had isolated cardiac injuries, whereas $40(42.5 \%)$ sustained additional injuries along with cardiac injuries, with the most common accompanying injuries being pulmonary injuries. Furthermore, they stated that the highest rate of mortality was observed in groups with accompanying pulmonary injuries. Our findings of accompanying pulmonary injuries are in line with the findings in the literature.

Evidence in the literature shows that echocardiography performed in the emergency department to detect hemopericardium in penetrating and blunt cardiac injuries is an important diagnostic intervention and that the use of ultrasonography reduces the time between a patient's arrival to the hospital and surgical intervention being performed. ${ }^{[9]}$ On the other hand, detailed examinations such as computed tomography can be performed in only a few hemodynamically stable patients. Echocardiography evaluation performed prior to surgery provides valuable information in valvular and atrial/ventricular injuries. Performing transesophageal echocardiography during the surgery, on the other hand, can be useful in evaluating intraventricular injuries and valve functions in patients for whom pre-surgery echocardiography cannot be performed. ${ }^{[10]}$

The results of our experiment showed that evaluation of the external surface of the heart is not sufficient to determine the severity of cardiac injury and/or the presence of accompanying pulmonary injury in injuries sustained following penetrating thoracic injuries. Physicians should therefore consider injuries to the external surface of the heart as the "tip of the iceberg" and explore for additional damage. Undetected intracardiac and pulmonary injuries may have complications and adverse effects during the post-surgery period. All these indicate that thorough pre-surgery preparation and surgical exploration for damage should be performed in patients with penetrating cardiac injuries. However, it is known that there is not enough time, equipment, or personnel available for the application of heart-lung machines in all cases with penetrating cardiac injuries.

Conflict of interest: The authors have no commercial associations or sources of support that might pose a conflict of interest. All authors have made substantive contributions to the study, and all authors endorse the data and conclusions. There is no conflict of interest between authors.

\section{REFERENCES}

1. Campbell NC, Thomson SR, Muckart DJ, Meumann CM, Van Middelkoop I, Botha JB. Review of 1198 cases of penetrating cardiac trauma. Br J Surg 1997;84:1737-40. CrossRef

2. Çakır Ö, Eren Ş, Balcı AE, Özçelik C, Eren N. Penetrating cardiac injuries. [Article in Turkish] Türk Göğüs Kalp Damar Cer Derg 1999;7:112-6.

3. Tokur M, Ergin M, Kurkcuoglu C. Penetrating heart injuries and common difficulties encountered during emergency surgery. J Curr Surg 2012;2:89-95.

4. Cha EK, Mittal V, Allaben RD. Delayed sequelae of penetrating cardiac injury. Arch Surg 1993;128:836-41. CrossRef

5. Jenson B, Kessler RM, Follis F, Wernly JA. Repair of atrial septal defect due to penetrating trauma. Tex Heart Inst J 1993;20:241-3.

6. Stahl RD, Liu JC, Walsh JF. Blunt cardiac trauma: atrioventricular valve disruption and ventricular septal defect. Ann Thorac Surg 1997;64:1466-8.

7. Kaplan M, Demirtaș M, Alhan C, Aka SA, Dağsalı S, Eren E, et al. Cardiac injuries: experience with 63 cases. [Article in Turkish] Türk Göğ̈̈s Kalp Damar Cer Derg 1999;7:287-90.

8. Yavuz C, Çil H, Başyiğit İ, Demirtaş S, İslamoğlu Y, Tekbaş G, et al. Factors affecting mortality in penetrating cardiac injuries: our 10-year. Turkish J Thorac Cardiovasc Surg 2011;19:337-43. CrossRef

9. Rozycki GS, Feliciano DV, Ochsner MG, Knudson MM, Hoyt DB, Davis $\mathrm{F}$, et al. The role of ultrasound in patients with possible penetrating cardiac wounds: a prospective multicenter study.J Trauma 1999;46:543-52. CrossRef

10. Meyer DM, Jessen ME, Grayburn PA. Use of echocardiography to detect occult cardiac injury after penetrating thoracic trauma: a prospective study. J Trauma 1995;39:902-9. CrossRef

\title{
DENEYSEL ÇALIŞMA - ÖZET
}

\section{Deneysel penetran toraks yaralanmasına bağlı kardiyak ve pulmoner yaralanmaların analizi}

\section{Dr. Mahmut Tokur, ${ }^{1}$ Mehmet Ergin, ${ }^{2}$ Mehmet Okumuş ${ }^{3}$}

\author{
${ }^{1}$ Sütçü İmam Üniversitesi Tıp Fakültesi, Göğüs Cerrahisi Anabilim Dalı, Kahramanmaraş: \\ ${ }^{2}$ Konya Necmettin Erbakan Üniversitesi Tıp Fakültesi, Acil Tıp Anabilim Dalı, Konya;
}

${ }^{3}$ Sütçü İmam Üniversitesi Tıp Fakültesi, Acil Tıp Anabilim Dalı, Kahramanmaraş

AMAÇ: Bu çalışmada, domuz deneklerde kasten yapılan torasik yaralanma sonucu meydana gelen kardiyak yaralanmaların iç ve dış anatomik bulguları ile eşlik eden pulmoner yaralanmaların incelenmesi amaçlandı.

GEREÇ VE YÖNTEM: Biz altı adet suis domesticus cinsi dişi domuz denekte penetran kardiyak yaralanma oluşturduk. Aynı araştırmacı tarafından $20 \mathrm{~cm}$ uzunluğundaki bistüri ile biri sağ paratrakeal 4. interkostal aralıktan (IKA) ve diğeri sol paratrakeal 4. İA'dan olmak üzere iki adet penetran kardiyak yaralanma gerçekleştirildi. Tüm hayvanlar morfolojik inceleme için sakrifiye edildi.

BULGULAR: Sol 4. İKA'dan uygulanan darbe neticesinde dış yüzey incelemesi \%50'sinde tek ve \%33.3'ünde birden fazla kesi oluştuğunu gösterdi. iç yüzey incelemesi ise beş denekte ek intrakardiyak yaralanma olduğunu gösterdi. Ancak dış yüzeyde tek yaralanması olan denekte birden çok iç yüzey yaralanması, dış yüzeyde birden çok yaralanması olan denekte ise bir adet intrakardiyak yaralanma tespit edildi. Sağ 4. iKA'dan uygulanan darbe sonucunda ise üç denekte yaralanma oluştuğu ve üç domuzdan iki tanesinde akciğer yaralanmasının mevcut olduğu görüldü.

TARTIŞMA: Bu deney, penetran toraks yaralanmaları sonucu oluşan kardiyak hasarın şiddetini ve eşlik eden akciğer yaralanmasını ortaya koymada, sadece kalp dış yüzey bulgularının yeterli olamayacağını işaret etmektedir.

Anahtar sözcükler: Miyokardiyal hasar; penetran; travma.

Ulus Travma Acil Cerrahi Derg 2014;20(4):227-230 doi: 10.5505/tjtes.20।4.58538 